UDC 341.942 .3

LBC 67.93

\title{
THE DIFFERENTIATION OF CRIMINAL PROCEEDINGS AND CRIMINAL LIABILITY
}

\author{
Anatoliy P. Kruglikov \\ Volgograd State University, Volgograd, Russian Federation
}

\begin{abstract}
Introduction: the Criminal and Criminal Procedure Codes of the Russian Federation provide for the duties whose violation is subject to criminal or criminal procedure liability. The author examines some issues of the nature and problems of the differentiation of criminal and criminal procedure liability where the scientific practitioners have different opinions. Results: in this article there is no need to dwell on the analysis of the debate on the issues of differentiating the responsibility in criminal law and criminal procedure. The author discusses and analyses the question of the impact of differentiating criminal proceedings on criminal liability. A brief legal description of certain types of differentiating criminal proceedings is presented. Conclusions: there is no doubt that the criminal procedure differentiation in some cases significantly affects the criminal liability, and not always correctly. The results of the study can be used in the improvement of the criminal procedure legislation and judicial and investigative practice.

Key words: differentiation of liability, criminal liability, differentiation of criminal proceedings, criminal procedure legislation, judicial and investigative practice.
\end{abstract}

УДК 341.942 .3

ББК 67.93

\section{ДИФФЕРЕНЦИАЦИЯ УГОЛОВНОГО СУДОПРОИЗВОДСТВА И УГОЛОВНАЯ ОТВЕТСТВЕННОСТЬ}

\author{
Анатолий Петрович Кругликов \\ Волгоградский государственный университет, г. Волгоград, Российская Федерация
}

\begin{abstract}
Введение: Уголовным и Уголовно-процессуальным кодексами Российской Федерации установлены соответствующие обязанности, за нарушение которых может наступать уголовная или уголовно-процессуальная ответственность. Исследуются отдельные вопросы о сущности и проблемах дифференциации уголовной и уголовно-процессуальной ответственности, по которым нет единства взглядов среди научных практических работников. Результаты: в рамках настоящей статьи нет необходимости подробно останавливаться на анализе полемики по вопросам дифференциации ответственности в уголовном праве и уголовном судопроизводстве. В ней рассматривается и анализируется вопрос о влиянии дифференциации уголовного судопроизводства на уголовную ответственность. Дается краткая правовая характеристика отдельных видов дифференциации уголовного судопроизводства. Выводы: представляется несомненным тот факт, что уголовно-процессуальная дифференциация в ряде случаев значительно влияет на уголовную ответственность, причем не всегда правильно. Результаты проведенного исследования могут быть использованы при совершенствовании уголовно-процессуального законодательства и в судебно-следственной практике.

- Ключевые слова: дифференциация ответственности, уголовная ответственность, дифференциация уго궁 ловного судопроизводства, уголовно-процессуальное законодательство, судебно-следственная практика.

\section{Введение}

Уголовным и Уголовно-процессуальным кодексами установлены соответствующие обязанности, за нарушение которых может насту-

пать уголовная или уголовно-процессуальная ответственность. М.С. Строгович отмечал: «Везде, где идет речь об обязанностях и их исполнении, неизбежно присутствует ответственность за надлежащую их реализацию» [8].
\end{abstract}


Вопросы о сущности и проблемах дифференциации уголовной и уголовно-процессуальной ответственности постоянно находятся в центре внимания научных и практических работников, по ним нет единства взглядов. Анализ уголовно-процессуального законодательства приводит к выводу о том, что установленный УПК РФ в ряде случаев особый порядок принятия судебного решения, при наличии для этого оснований, выступает в качестве определенной процессуальной формы реализации уголовной ответственности.

\section{Влияние дифференциации уголовного судопроизводства \\ на уголовную ответственность}

Установленный уголовно-процессуальным законом порядок привлечения к уголовной ответственности и освобождения от нее, многие другие проблемы невозможно правильно разрешить без выяснения центрального вопроса: что такое уголовная ответственность, какова ее сущность?

А.В. Наумов дает следующее понятие уголовной ответственности: «Под уголовной ответственностью следует понимать меры принудительного характера, которые предусматриваются уголовным законом в качестве реакции государства на совершение лицом преступления. В конечном счете уголовная ответственность заключается в реализации санкций уголовно-правовых норм» $[5$, с. 33$]$.

Чтобы уголовная ответственность была реализована, необходима установленная уголовно-процессуальным законом деятельность органов предварительного расследования, осуществляемая под ведомственным контролем и прокурорским надзором, для совершения определенных законом действий нужно получить разрешение суда.

Можно назвать некоторые этапы уголовно-процессуальной деятельности: установление и изобличение при помощи доказательств лиц, виновных в совершении преступлений, привлечение их в качестве обвиняемых, избрание в отношении обвиняемых соответствующих мер пресечения и т. д.

При этом необходимо учитывать, что обвинение, сформулированное в актах органов предварительного расследования, по своей значимости и последствиям отличается от обвинения, изложенного в приговоре суда. Обвинение, сформулированное в досудебном производстве, не предрешает судебного решения о виновности, не является основанием для применения наказания.

Анализ уголовного и уголовно-процессуального законодательства приводит к выводу о том, что существующая дифференциация уголовного судопроизводства в ряде случаев значительно влияет на уголовную ответственность. И здесь необходимо отметить, что дифференциация уголовного судопроизводства тесно связана с вопросом о понятии уголовно-процессуальной формы и относящимися к ней проблемами.

\section{Процессуальная форма и ее дифференциация: сущность и содержание}

Разные авторы понятие проиессуальной формы и ее содержание определяют во многом одинаково. Что же касается вопроса о дифференциации проиессуальной формы, то здесь одинаковое понимание у авторов отсутствует. По обоснованному мнению Н.С. Алексеева, В.Г. Даева, Л.Д. Кокорева, «проблема процессуальной формы наиболее остро ставится в связи с вопросом о дифференциации процесса. Дифференциация осуществляется в основном по двум направлениям: 1) установление дополнительных гарантий законности по отдельным категориям уголовных дел (дела о преступлениях несовершеннолетних, лиц, страдающих психическими или физическими недостатками и т. д.); 2) упрощение некоторых процессуальных форм для дел о преступлениях, не представляющих большой общественной опасности» $[1$, c. 33].

В литературе отмечено: «Анализ требований, предъявляемых к дифференциации процессуальной формы, позволяет выделить основные из них. Они следующие: 1) правильное определение ее оснований и целей; 2) ненарушение предусмотренных соответствующими международными правовыми актами, Конституцией РФ и УПК РФ прав и свобод граждан, вовлеченных в уголовное судопроизводство; 3) чтобы был сохранен общий еди- 
А.П. Кругликов. Дифференциация уголовного судопроизводства и уголовная ответственность

ный порядок судебного разбирательства уголовных дел» [3, с. 46].

\section{Особый порядок}

\section{судебного разбирательства:}

отдельные виды и сущность

С учетом приведенных требований к процессуальным формам рассмотрим лишь некоторые виды современной дифференциации уголовного судопроизводства, реализация положений которых прямо связана с вопросом об уголовной ответственности лиц, вовлеченных в уголовный процесс. Назовем эти виды: 1) особый порядок принятия судебного решения при согласии обвиняемого с предъявленным ему обвинением; 2) особый порядок принятия судебного решения при заключении досудебного соглашения о сотрудничестве; 3 ) производство дознания в сокращенной форме.

В приведенных особых порядках имеются определенные отличия, относящиеся к судебному разбирательству уголовных дел. Но есть и то общее, весьма существенное, что позволяет сделать выводы, затрагивающие все названные особые порядки производства. И это «общее» содержится в ст. 316 УПК РФ, устанавливающей порядок проведения судебного заседания и постановления приговора при согласии обвиняемого с предъявленным ему обвинением. Частью 5 ст. 316 УПК РФ предписано: «Судья не проводит в общем порядке исследование и оценку доказательств, собранных по уголовному делу» (выделено мною. - А. К.). Частью 7 ст. 316 УПК РФ определено: «Если судья придет к выводу, что обвинение, с которым согласился подсудимый, обоснованно, подтверждается доказательствами, собранными по уголовному делу, то он постановляет обвинительный приговор и назначает подсудимому наказание, которое не может превышать две трети максимального срока или размера наиболее строгого вида наказания, предусмотренного за совершенное преступление».

Из приведенных положений ст. 316 УПК РФ сделаем промежуточный вывод: в судебном заседании исследование и оценка доказательств не проводятся, но подсудимому может быть назначено наказание значительно меньшее, чем ему могло бы быть назначено при рассмотрении дела в обычном порядке.

Аналогичный порядок применяется к принятию судебного решения при заключении досудебного соглашения о сотрудничестве (ст. $317^{7}$ УПК РФ) и к производству дознания в сокращенной форме (ч. 1 ст. $226^{9}$ УПК РФ).

И здесь возникает вопрос: становится ли лищо менее общественно опасным, если оно согласилось на проведение особого порядка судебного заседания с иелью получить менее тяжкое наказание, чем оно получило бы при рассмотрении дела в общем порядке? Достигаются ли в таких случаях иели наказания, указанные в $\mathrm{cm} .43$ УК РФ? При установлении того или иного сокращенного порядка судопроизводства законодатель нигде не ставит целью, чтобы виновный не получил бы того наказания, которое он понес бы без дачи согласия обвиняемым на ускоренное судопроизводство.

Нельзя отрицать и тот факт, что в указанных случаях может быть осужден невиновный, так как его вина не была подтверждена доказательствами, исследованными в ходе полноиенного судебного разбирательства. Полагаю, что дифференциация уголовного судопроизводства в указанных случаях своей цели не достигла.

\section{Качество предварительного расследования и взгляды ученых на отдельные виды дифференциации}

Применительно к положениям ст. 316 УПК РФ А.Н. Халиков верно указал: «при таком порядке проведения судебного заседания отсутствуют прения сторон по вопросам квалификации деяния, вида и меры наказания, не предусмотрено последнее слово подсудимого, и что это совсем не похоже на правосудие» $[9$, с. $64-65]$.

Заслуживает внимания мнение известного адвоката, члена Общественной палаты РФ, председателя Общественного совета при МВД профессора Анатолия Кучерены, изложенное им на страницах «Российской газеты»: «Особенно тревожит поставленное на поток рассмотрение дел в судах в так называемом особом порядке. На сегодняшний день 64 процента уголовных дел по стране рассматрива- 
ется именно в таком порядке... Фактически мы опять обращаемся к средневековому принципу, когда признание вины считалось царицей доказательств [7].

В литературе отмечено: «Заслуживает внимания и такой факт: впервые при включении в УПК РФ новой главы - $32^{1}$ «Дознание в сокращенной форме» законодатель дважды (!) упоминает о возможном самооговоре обвиняемого» [3, с. 49].

Нельзя обойти и вопрос о качестве предварительного расследования в настоящее время. Это «качество» прослеживается из сведений, приведенных генеральным прокурором РФ Ю.И. Чайкой в докладе «О состоянии законности и правопорядка в 2016 году и о проделанной работе по их укреплению», с которым он выступил на заседании Совета Федерации Федерального Собрания Российской Федерации 26 апреля 2017 года. В докладе, в частности, отмечено: «Не буду много говорить о следственной составляющей в деятельности правоохранительных органов. Выражу общее мнение прокуроров, что повсеместно следствие “проседает”». Количество выявленных прокурорами нарушений в деятельности всех органов предварительного расследования за год вновь возросло, превысив 5 млн» [2]. И при таком «качестве» предварительного расследования в стране действуют особые порядки принятия судом решения!

\section{Выводы}

Какой же выход может быть из сложившегося положения? Думается, только один: «после проведенного предварительного расследования необходимо проводить полноценное судебное разбирательство, состоящее из подготовительной части, судебного следствия, судебных прений, последнего слова подсудимого и постановления приговора. Лишь таким путем можно будет избежать самооговоров обвиняемых, нарушений прав и свобод граждан, вовлеченных в уголовное судопроизводство, способствовать установлению объективной истины по уголовному делу» [4].

Прав П.Ф. Пашкевич, когда еще применительно к существовавшей в советский период протокольной досудебной подготовке уголовных дел писал: «Опытом давно дока- зано, что ни истина, ни справедливость, ни законные интересы и права обвиняемого ничуть не страдают, если такие дела незамедлительно становятся предметом судебного разбирательства после самой элементарной досудебной подготовки» [6, с. 65].

Изложенное приводит к выводу о том, что рассмотренные в статье виды дифференциации уголовного судопроизводства не способствуют установлению истины по уголовным делам, не снижают общественной опасности лиц, совершивших преступления, в том числе посредством назначения им не того наказания, которое они могли бы получить при рассмотрении дела в общем порядке.

Автор понимает, что содержащиеся в статье выводы небесспорны, но убежден в том, что рассмотренные в статье проблемы нуждаются в дальнейшем исследовании.

\section{СПИСОК ЛИТЕРАТУРЫ}

1. Алексеев, Н. С. Очерк развития науки советского уголовного процесса / Н. С. Алексеев, В. Г. Даев, Л. Д. Кокорев. - Воронеж : Изд-во Воронежского государственного университета, 1980. - 251 с.

2. Доклад Генерального прокурора РФ на заседании Совета Федерации Федерального Собрания Российской Федерации 26 апреля 2017 г. - Электрон. текстовые дан. - Режим доступа: https:// genproc.gov.ru/smi/interview_and_appearences/ appearences/1187305/ (дата обращения: 08.06.2017). Загл. с экрана.

3. Кругликов, А. П. Дополнение УПК РФ новой главой о дознании в сокращенной форме и некоторые проблемы дифференциации уголовного судопроизводства / А. П. Кругликов // Российская юстиция. - 2013. - № 7. - С. 45-49.

4. Кругликов, А. П. К вопросу об истине в уголовном судопроизводстве / А. П. Кругликов // Российская юстиция. - 2013. - № 1. - С. 42-46.

5. Наумов, А. В. Основание уголовной ответственности / А. В. Наумов // Комментарий к Уголовному кодексу Российской Федерации / отв. ред. В. М. Лебедев. - М. : Юрайт-Издат, 2004. - 917 с.

6. Пашкевич, П. Ф. Процессуальный закон и эффективность уголовного судопроизводства / П. Ф. Пашкевич. - М. : Юридическая литература, 1984. $-176 \mathrm{c}$.

7. Российская газета. $-2015 .-20$ янв.

8. Строгович, М. С. Сущность юридической ответственности / М. С. Строгович // Советское государство и право. - 1979. - № 5. - С. 72-78. 
А.П. Кругликов. Дифференциация уголовного судопроизводства и уголовная ответственность

9. Халиков, А. Н. Вопросы, возникающие при особом порядке судебного разбирательства / А. Н. Халиков // Российская юстиция. - 2003. № 1. - C. $63-65$.

\section{REFERENCES}

1. Alekseev N.S., Daev V.G., Kokorev L.D. Ocherk razvitiya nauki sovetskogo ugolovnogo protsessa [Essay on the Development of Science of the Soviet Criminal Procedure]. Voronezh, Izd-vo Voronezhskogo gosudarstvennogo universiteta, 1980. $251 \mathrm{p}$.

2. Doklad Generalnogo prokurora $R F$ na zasedanii Soveta Federatsii Federalnogo Sobraniya Rossiyskoy Federatsii 26 aprelya $2017 \mathrm{~g}$. [The Report of the Prosecutor General of the Russian Federation at a Meeting of the Federation Council of Federal Assembly of the Russian Federation on April 26, 2017]. URL: https://genproc.gov.ru/smi/interview_and appearences/appearences/1187305/. (accessed June 8, 2017).

3. Kruglikov A.P. Dopolnenie UPK RF novoy glavoy o doznanii v sokrashchennoy forme i nekotorye problemy differentsiatsii ugolovnogo sudoproizvodstva [The Supplementation of the Criminal Procedure Code of the Russian Federation with the New Chapter about Inquiry in Abbreviated Form and Some Problems of Criminal Legal Proceedings Differentiation]. Rossiyskaya yustitsiya, 2013, no. 7, pp. 45-49.

4. Kruglikov A.P. K voprosu ob istine v ugolovnom sudoproizvodstve [On the Truth in Criminal Legal Proceedings]. Rossiyskaya yustitsiya, 2013, no. 1, pp. 42-46.

5. Naumov A.V. Osnovanie ugolovnoy otvetstvennosti [The Base of Criminal Liability]. Lebedev V.M., ed. Kommentariy k Ugolovnomu kodeksu Rossiyskoy Federatsii [The Commentary to the Criminal Code of the Russian Federation]. Moscow, Yurayt-Izdat Publ., 2004. 917 p.

6. Pashkevich P.F. Protsessualnyy zakon $i$ effektivnost ugolovnogo sudoproizvodstva [Procedural Law and Efficiency of Criminal Legal Proceedings]. Moscow, Yurid. lit-ra, 1984. 176 p.

7. Rossiyskaya gazeta, 2015, January 20.

8. Strogovich M.S. Sushchnost yuridicheskoy otvetstvennosti [Essence of Legal Responsibility]. Sovetskoe gosudarstvo i pravo, 1979, no. 5, pp. 72-78.

9. Khalikov A.N. Voprosy, voznikayushchie pri osobom poryadke sudebnogo razbiratelstva [The Questions Arising in Case of a Special Order of Judicial Proceedings]. Rossiyskaya yustitsiya, 2003, no. 1, pp. 64-65.

\section{Information about the Author}

Anatoliy P. Kruglikov, Candidate of Juridical Sciences, Professor, Department of Criminal Procedure and Criminalistics, Volgograd State University, Honored Worker of Higher Professional Education of the Russian Federation, Prosp. Universitetsky, 100, 400062 Volgograd, Russian Federation, upik@volsu.ru.

\section{Информация об авторе}

Анатолий Петрович Кругликов, кандидат юридических наук, профессор кафедры уголовного процесса и криминалистики, Волгоградский государственный университет, почетный работник высшего профессионального образования РФ, просп. Университетский, 100, 400062 г. Волгоград, Российская Федерация, upik@volsu.ru. 